\title{
Portuguese Defence Activities at Macau During the Boxer Uprising
}

\author{
Teddy Y. H. Sim \\ National Institute of Education, Nanyang Technological University \\ researchcl@gmail.com
}

\begin{abstract}
This article examines Portuguese colonial and military activities at Macau during the Boxer Uprising of 1900, connecting developments across the border in Guangdong with initiatives undertaken by the colonial authorities in Macau. The Portuguese perceived the situation to be serious enough that substantial reinforcements were eventually sent from the metropole, in addition to various other measures taken to strengthen the colony's defenses. Portugal also used Macau as a base to coordinate the operations of its consulates in China, and exploited the Boxer debacle to press for new concessions and other advantages at China's expense. At the end, it is hoped that the limited and relatively unknown role played by Portugal, in conjunction with the larger kaleidoscope of events around Macau, may be better illuminated.
\end{abstract}

\section{Keywords}

Macau - Boxer Uprising - events of 1900 - Portuguese Far East - Portuguese colonialism - Portuguese military history

\section{Brief Survey}

A somewhat sceptical source describes Portugal as having "participated in the [Allied] suppression" of the Boxer Uprising. . While it is entirely possible for a state to be involved in an international campaign in a low-key role, as a few countries were in the Gulf War of 1990-91, the author of this article has

1 Clarence-Smith 1985, 3. 
not seen any fuller treatment on this piece of information about Portugal. W. G. Clarence-Smith's observation cited above formed the first spark of motivation for this study. Although the historiography of the literature relating directly to the Boxer Uprising has advanced greatly since Victor Purcell's Boxer Uprising (1963) and Chester Tan's Boxer Catastrophe (1967), Lanxin Xiang's multinational study on the origins of the uprising reveals the many gaps in historiography. ${ }^{2}$ Xiang originally intended to "complete a comprehensive history of the [event] by 2000" to coincide with its centennial, but his work evolved to writing about the origins alone. The event has also received attention in diverse sub-fields. Paul Cohen, exploring the Boxers in the context of "three keys" (event, experience, and myth), examines the events surrounding the Boxer Uprising from an academic perspective, looks at the experiences of multiple groups, and analyses the event in relation to contemporary references and distortions. ${ }^{3}$ Dealing with the thinking and mindset involved is not only compatible with the postmodern intellectual trend of exploring sensibilities, it also engages the point of view of the other side. This positions the subject matter obliquely in a once hotly debated area of China studies - that is, whether studies could be less Western-centric and look into domestic impulses to explain developments in China. The consideration of multiple perspectives ("event" and "experience") does not mean that these views can be disentangled (or reconciled). Elsewhere, as Xiang has acknowledged, even as a more exhaustive understanding of evidence is gleaned from multinational origins, that much more can be done to understand the event. From the perspective of the historiography of imperialism, the Allies' collaborative efforts in the Chinese uprising of 1900 belied the fact that this was one of the most intensely competitive periods in the history of Western imperialism. Apart from the major participants in the 1900 multinational expedition, there is room to examine the host of smaller Western powers that had a presence in China before and after the event to see whether they could extract any privileges from China.

This essay does not dwell on the origins of the Boxer Uprising or significant developments associated with the main protagonists (China and the major sponsoring powers of the expeditionary forces), or the wider historiographical issue of how the event was used both then and later; instead, it is viewed from the perspective of a longstanding but small colonial power that ruled Macau (Aomen 澳門). The Portuguese in Macau during the Boxer Uprising have hardly been studied: since Portugal was never a formal participant in the conflict, it is natural to assume that there would be little to write about. Exploring

2 Xiang 2003, preface.

3 Cohen 1997. 
diplomatic communications and exchanges as well as journalistic reporting of the day, this article highlights the effect of the Boxer Uprising on the south, particularly Macau, due to the interrelationships among dissident groups and events linked to the settlement. It also assesses the defence status of Macau and briefly probes into the resources and manpower Portugal allocated to Macau during the uprising. It delves into the consequences of Macau's involvement, especially the Portuguese colonial military reforms undertaken toward the end of the crisis in north China. Linking with the historiography of imperialism and military history, the article discusses the paradoxical situation of how a minor and somewhat precarious colonial state (Portugal) prepared itself in times of instability as well as sought to expand its boundaries and influence on the coast of China. This study draws upon bulletins published during the Boxer Uprising in Macau and its vicinity. Much of the diplomatic correspondence is printed in collections such as the Sino-Portuguese Roll of the Collected Records of the Qing Foreign Affairs Office and the collected records on Macau (Aomen Zhuandang 澳門專檔). The study also draws on information housed in the Historical Archives of Macau, such as microfilm copies of documents held in Lisbon relating to telegraphic exchanges between Macau and the metropole, as well as routine paperwork on the military logistical needs of the colonial settlement. Documents from the Historical Diplomatic Archive (Portuguese Ministry of Foreign Affairs) and Historical Military Archive in Lisbon were also consulted directly. On the Chinese side, this article looks at letters received and sent by Li Hongzhang 李鴻章, the governor-general of Liangguang (Guangdong and Guangxi) at the time of the crisis. ${ }^{4}$

\section{The Uprising and the Larger Context}

The world in the last quarter of the nineteenth century was one in which Western nations, whether they were first-rate (like Britain) or second- or

4 The records drawn from the Arquivo Historico Macau (A.H.M.) include those from the Direcção-Geral (general directorate) do Ultramar (created 1868) and the Gabinete (cabinet/ office) do Ministro (created 1892). Up until the establishment of the Republic, the General Directorate underwent a few internal changes. The documents of the General Directorate are organised (according to Abrantes 1999) under the A.H.M. and classified into those of the three departments with which it was originally created and another four departments into which it was later organised (in 1878 with six departments). Other than the Gabinete, the documents of the Overseas Council appear to be separately organised as well, being dated to 1868. The evolution of the Council entailed its own developments—its influence and actual 
third-rate, were engaged in a frenzy of colonization and privilege-grabbing activities. ${ }^{5}$ The main competition in the second half of the nineteenth century was for Africa. Portugal, although third-rate among the expanding powers, was not indifferent to the opportunities available. The country was, however, often vulnerable and had to rely on the good faith of the signatories of international agreements and the good graces of its allies. In Portugal's empire in the East, Goa and Macau were deemed self-sufficient and Portugal did not want to lose them, as they might be of use in the future. ${ }^{6}$ In the case of Macau, it might be of interest to keep in mind that Timor, which required an injection of funds to develop its mines, had been joined with the former as an overseas province in 1883 .

China in the second half of the nineteenth century was attempting to catch up and industrialize after its rude defeat and forced opening after the Opium War (1839-1842). By the third quarter of the nineteenth century (after the Second Treaty Settlement), at least a dozen ports in China were open to foreign trade. Although the economic network appeared to have expanded, it would be far-fetched to speak of a national market. ${ }^{7}$ Traditionally, linkages in the south were better than elsewhere due to the region's more intricate inland water routes. ${ }^{8}$ Foreign stakes (notably British) along and below the Yangzi River increased considerably after the $1870 \mathrm{~s}$. By the end of the century, Britain had grown to become a relatively significant trading partner of China. Hong Kong played an important role in British economic interests in China. In 1880, China exported slightly more than 20 per cent and imported almost 40 per cent of its goods through Hong Kong. From the mid-188os to just prior to 1898, Hong Kong's share in external trade rose by 10 per cent-from one-third to over 40 per cent. However, warehouse capacity in Hong Kong was not able to cope with the increase in external trade. ${ }^{9}$ Macau undertook to fill the additional

operations having oscillated since its formation in 1643. Though it was formally terminated by a decree in 1833, it was briefly revived in 1851 and lasted another seventeen years (to 1868).

5 Kennedy 1989, 143-93. An exception in the Western-dominated group of imperialist powers was Japan. The country was able to modernise within a relatively short time after its forced opening by United States in 1853 . In the last decade of the nineteenth century, it defeated its larger neighbor China and was poised for the partitioning scramble with the other imperialist powers in that country.

6 Clarence-Smith 1985, 82 .

7 Feuerwerker 1984, 44.

8 Although railway mileage was increased and more steamships were sailing up the inland rivers, railways did not have an effect till the last years of the dynasty.

9 Yu 1994, 240-66. 
storage and transshipment needs until the widespread use of steamships in the late nineteenth century. ${ }^{10}$

Portugal had been trying to enter and assert its influence on the regions surrounding Macau whenever the opportunity arose. The immediate event leading up to the Boxer Uprising was Portugal's attempt to build a monument (bei 碑) on Da Heng Qin 大横琴. A. V. de Saldanha has analysed how the leasehold status of the New Territories in Hong Kong in 1898 spurred the Portuguese to ask for a delimitation and clarification of Macau's boundaries and status. ${ }^{11}$ The New Territories lease itself was a move by the British, who had acquired Weihaiwei 衛海威 earlier, in reaction to an apparent "scramble and carving up" of China after the latter's defeat in the Sino-Japanese War of $1894-95 \cdot{ }^{12}$

There were a number of occasions when Macau came under attack by would-be occupiers. Apart from the Dutch incursion almost three centuries earlier, the British briefly occupied Macau for a few months at the end of 1808 . While there was a fierce fight in the first incursion, it is doubtful whether the British takeover was hostile. In between, Macanese insecurity persisted throughout the eighteenth century. ${ }^{13}$ Was there any danger of a takeover by the Chinese? Except for Portugal's uncertainty of stay during the transitional period of dynastic change, the Portuguese privilege of remaining in Macau was sometimes understood as "a gesture of favor from the emperor of China."14 For the Chinese, there was hardly ever a need to launch a formal attack across the

\footnotetext{
$10 \quad$ Shipp 1997, 75 .

11 Saldanha 1996, 591.

12 The Germans acquired the leasehold of Jiaozhou Wan (which included Qingdao), the Russians acquired Port Arthur, and the French, Guangzhou Wan. Despite the loss of limited and what appeared to be strategically located territories, China was not dismembered by the imperialist powers, curbed by the insecurity of the powers and the need that each felt to balance and check the others. Unofficial and overlapping spheres of influence were, however, created in different parts of China, usually extending from the leaseholds and ceded territories granted to the imperialist powers.

13 Sim 2007, 106-20.

14 Regarding the Chinese reliance on the Portuguese to ward off bandits, there does not appear to be a final verdict on the subject. Although L. R. Guerreiro and B. Basto da Silva in the 199os continued to reiterate the view of "Macau as a bestowal to the Portuguese in exchange for the Portuguese provision of security," other Portuguese scholars such as M. Teixeira do not agree. Ljungstedt, (1836) has been interpreted simultaneously as being favourable and unfavourable towards the thesis. The Portuguese were indeed recorded as having made forays against pirates off the coast of China after their settlement in Macau. During the period of the Boxer Uprising, primary documents reveal the governor of Canton or inhabitants of the disputed islands asking the Portuguese for help against the pirates although not all of these requests were acceded to.
} 
border. All they had to do was cut off vital supplies and the city would be starved into surrender. ${ }^{15}$ Macanese concerns were reflected in an August 1900 telegram to Lisbon regarding the impact of a water shortage on the defence of the city. ${ }^{16}$ Nevertheless, in the decade leading up to the Boxer Uprising, China-in response to the accelerated imperialism after 1895 - had been actively asserting its influence on the areas it disputed with Portugal. On assuming his responsibility as governor of Macau in 1894, José M. de Sousa Horta e Costa pointed out that the Guangdong provincial authorities had not been respecting the articles of the 1887 Luso-Chinese treaty. The Guangdong authorities had tried to extract contributions from the inhabitants of the islands of D. João and Mong-ha, in the process provoking a standoff with Portugal. ${ }^{17}$

On the maritime front, piratical activities plagued Macau from its inception. Technically speaking, a bandit on the sea could not be distinguished from one who operated on land. The severity of the piratical threat from the sea could be seen to correlate with the different periods of piracy in the South China Sea. ${ }^{18}$ M. Teixeira wrote in an article that in 1902 the islands of Taipa, Coloane, and D. João continued to be harassed by indigenous Chinese pirates hiding on the rocky and mountainous island of Vong Cam. The pirates engaged in robbery, intercepting steamships going to and from Hong Kong, and kidnapping. Although posing no direct danger to Macau, these pirates could potentially disrupt livelihoods in the settlement. ${ }^{19}$ This was corroborated by the news received at the office of the neighboring colonial power in Hong Kong that "pirates in the rivers are robbing and giving rise to vexation" corresponding to the peak of activities in the north and across the province of Guangdong. ${ }^{20}$ Inhabitants of the disputed offshore islands, and even the governor of Canton,

15 Macau not only has few natural resources but also little space for the growing of crops. Other than food supplies, Macau has traditionally relied for water on the mainland, itself dependent on the Xijiang River.

16 A.H.M. (Macau) SSC 1a Repartição, SR 001, 1900.

17 Santos Alves 1999, 283-90.

18 European pirates (such as those of the Dutch, French, and English) were also present during certain periods on the coasts of China. Distinction of these sometimes depended on the side of a war or conflict metropolitan Portugal was involved in. When Portugal was allied with Britain in the Napoleonic Wars, for instance, isolated French ships operating in the Far East automatically became labeled as "piratical." Two periods in which piracy was particularly disruptive were during the first half of the seventeenth century and at the end of the eighteenth and beginning of the nineteenth centuries.

19 Teixeira 1984, 340-41.

20 Porvir 155, October 1900. 
sometimes asked the Portuguese for help against the pirates—although not all of these requests received a response. ${ }^{21}$

Although this article does not delve into the origins or categorisation of the Boxers, it attempts to classify the instigators of disturbances in the vicinity of Macau and across the border in Guangdong based on what is already known. It is possible to identify three broad groups in south China that were either directly or remotely linked to the Boxers, or that were not linked to the Boxers but were able to foment their own disruptions during the upheaval: (1) Boxers or pseudo-Boxers, (2) unrelated troublemakers, and (3) revolutionaries and associated rebels. These categories, especially the first two, are not mutually exclusive. This categorisation may not be ideal, but it can still help facilitate the discussion. While the Boxers might have continued to be associated, in the eyes of a contemporary Westerner, with the Qing authorities in Beijing, this association held less credibility in the south because officials in certain provinces had declared a policy of detachment from the Boxers that was contrary to that of the center. On the ground, and at the lower levels, there was always the potential for differentiation to be obfuscated as well; according to an early theory, some Boxers were actually discharged militias. ${ }^{22}$

Looking at the first group, how far south were the Boxers found? In the third run of the series of the journal Ta-Ssi-Yang-Kuo (Da Xiyang Guo, 大西洋國), a bimonthly journal on aspects of the Portuguese in the East run by João F. Marques Pereira, record was made of a certain telegram from Hong Kong to the governor of Macau, of which the journal was well-informed, which reported the burning of villages (especially Christian villages in the vicinity of Canton) and escalation of agitation. ${ }^{23}$ The journal was up-to-date with developments of the Boxer Uprising, for example featuring reports of the fighting at Taku and the expedition of Admiral Seymour; it also noted that the disturbance had been confined to north China. ${ }^{24}$ Cemeteries of Portuguese communities in the north had been violated. The journal raised the possibility of an attack on Macau by the Boxers. ${ }^{25} \mathrm{~A}$ debate arose as to whether there was

21 A.H.D. Caixa 1236, Relatorio do conselheiro Horta e Costa, 24 September 1900; A.H.D. Caixa 1229, Documento de Legação de Portugal na China, Japão e Siam, 24 August 1901.

22 Xiang 2003, preface.

23 TSYK 717. The journal Ta-Ssi-Yang-Kuo was founded by José Gabriel Fernandes and ran issues from October 1863 to April 1866. The journal was later revived in the form of Ta-SsiYang-Kuo, archivos e annaes do Extremo-Oriente Português by J. F. Marques Pereira from 1899 to 1900 and focused on the "issue of Macau" arising between China and Portugal.

24 TSYк 656-59, 659-6o.

25 TSYK 715 . 
a need, from a military point of view, to incorporate the islands surrounding Macau (particularly Lapa) in order to ensure these islands' safety. This argument became even more convincing when the British and Japanese recognised Portuguese rights over the islands. ${ }^{26}$ Going by the criteria examined by Joseph Esherick, the culprits causing disturbances in south China were anti-Western or anti-Christian, but it cannot be said for sure whether they practiced some form of martial art or embraced spirit-possessing rituals as the Boxers did. ${ }^{27}$

The second category of disrupters-unrelated troublemakers, who were Boxer sympathisers with varying degrees of affiliation - could be found in the south even though the Boxer Uprising was far to the north. At one extreme were ordinary bandits who might have torched a Christian establishment during a theft and had nothing to do with the Boxers. An entry in issue 122 of Zhi Xin Bao 知新報 cautioned beggars to be careful not to be mistaken for Boxers, ${ }^{28}$ showing the extent to which unrelated people in unconnected disturbances were likely to have been implicated. An increase in the incidence of natural disasters around 1900, coupled with reactions to the heightened foreign presence, sparked a number of riots in Guangdong province. The delta and the coast were the realm of pirates, who constituted a separate class and caused disruptions and havoc to ships coming into port.

Further complications arose from the fact that there were people affiliated with associations or bodies that had pledged to overthrow the Qing dynasty. For the restorationists under Kang Youwei and the revolutionists under Sun Yatsen, the Boxer upheaval and dislocation of the central government in the north presented a crucial opportunity to stage their secessionist moves-namely, to wrest control of Guangdong and initiate a northward offensive. Kang's plans sounded grandiose, with the promise to mobilise "tens of thousands of armed men and soldiers in different parts of the country," ${ }^{29}$ but did not materialise into an uprising of his own planning. As for Sun, his second and last uprising under the aegis of the Revive China Society (Xingzhong Hui, 興中會) took place in the region south of the Yangzi River in August 1900-at about the time the Eight-Power expedition was making its way to Beijing — and in Guangdong in October, two months after hostilities had apparently ceased in Beijing. ${ }^{30}$

\footnotetext{
26 TSYK 719.

27 Esherick 1987, xiii-xix, 315-20.

28 Zhi Xin Bao 1897, 1829.

29 Bing 2004, 71.

$30 \quad$ Wu 1991, 23-25. Strictly speaking, the August 1900 Hankou uprising was not of Sun Yatsen's planning but the work of diehard revolutionaries such as Tang Caichang (a compatriot of Tan Sitong, who had passed away in 1898), although it did receive Sun's endorsement. The
} 
Telegraphic exchanges contained updates on tensions arising from Chinese attempts to quell the unrest in Guangdong province. ${ }^{31}$ The unrest was further corroborated by news reports in Porvir in October and, especially, November $1900 .{ }^{32}$ Japan, as Marius Jansen affirms, had supported Sun's uprising until the change of government at home caused a change in the direction of policy and sponsorship. ${ }^{33}$ Porvir issue 153 reported on the Guangdong Rebellion, in which rebels pressed toward the border of Kowloon, where they were met by a force of several hundred British and colonial soldiers. Apparently, rebels there "mauled" (derrotar) Qing troops along the border of the province. ${ }^{34}$ In Porvir issue 155, it was reported that rebels were attacking imperial troops at Sam Kokfu. The initial victory of the rebels heightened anti-foreigner sentiment among local common folk and villagers. The newspaper clarified that these rebels were unrelated to Boxers - or even secret societies—because missionaries vouched for their leaders and these rebels had links with "co-religionists in Singapore and America." The tension in Macau is evident from the following communication from the governing council of Macau to the centre (Lisbon):

It is supposed that the telegraphic communications [to] Hong Kong have been cut. They [lower functionaries of the colonial government of Macau] have sent the secret police to the outskirts to find out the intentions of China. They say somebody enticing [the people] to revolution appeared from the north, [and] the people are favourable. The council took the necessary measures together with the commander of the land and sea [forces] for the defence of the colony. It passed the authorisation for the reorganisation of the "national battalion," all disposed to the defence of the colony. ${ }^{35}$

uprising apparently also obtained the support of Kang Youwei (who did not see eye-toeye with Sun). The failure was traced in part to the late or non-arrival of funds that Kang was supposed to raise. The 6 October uprising late in the same year broke out specifically in Guangdong's Hui county and, although it enjoyed some initial success, petered out before the end of the month as resources were exhausted.

31 A.H.M. (Macau) SSC: $1^{\text {a }}$ Repartição, SR 001, 6 September 1900.

32 Porvir 153-55, October 1900; Porvir 156-58, November 1900. The collection was accessed at the Biblioteca do Edificio of the Instituto para os Assuntos Cívicos e Municipais (I.A.C.M., Macau).

33 Jansen 1954, 202-12.

34 Porvir 153 , October 1900.

35 Porvir 155, October 1900. 
From the perspective of the Qing government, it was important to destroy the rebels in the south even while the court was on the run in 1901. However, the stance on the Chinese side was not consistent. The entanglement of the local Qing governors and foreign powers in the Boxer Uprising revealed various overlapping self-interests. In the few years before 1900 (through the short-lived Hundred Days' Reform), factionalism in the Qing court evolved in a complex way. Those with reformist tendencies could be divided into moderates and radicals. Their attitudes pertaining to the nature of reforms to be undertaken were not necessarily uniform, although both were pacifist toward the Western powers. From the reverse angle, the Russians supported the conservative camp, while the British and Japanese-with whom the Portuguese were likely to be linked - got along better with the reformists. It was the conservatives (associated with figures such as Prince Duan 端王) who had been most xenophobic about the Western presence and Western-inspired reforms. ${ }^{36}$

The initiative to preserve the south was the brainchild of Liu Kunyi 劉坤一 and Zhang Zhidong 張之洞, both of whom ignored the imperial edict to declare all-out war against foreigners in the south. In a telegram to a Portuguese consul, Zhang (governor-general of Huguang with authority over Hubei and Hunan) supported Liu's idea of taking steps to protect foreigners and their properties in ports along the Yangzi as well as coordinating with the taotai of Shanghai to protect the foreign community there. ${ }^{37}$ For Li Hongzhang, his eight-month stint as governor-general of Liangguang was not the most desirable appointment. At seventy-seven, Li had participated in major events in the last quarter of the nineteenth century. His affiliations were not easy to disentangle. Apart from the legitimate reasons to dispatch Li to the south, the assignment was also a result of political maneuvering at court. Li's initial assignment to the south was as superintendent of trade, but he was abruptly reappointed as governorgeneral of Liangguang to deal with reformists on the run. He initially made his own decisions about what to do on the ground, which showed his complexity as a political actor. During his reluctant tenure at Guangzhou, Li Hongzhang also tried to ensure that the interests of the foreign powers in Liangguang were not violated, governing the provinces of Guangdong and Guangxi with the

36 Chang 1980, 274-338; Hsu 1980, 70-141. Other than the more general treatment on the various reformist factions and their evolution, see also individual biographies of Liu Kunyi (Wang 1990, 142-74), Zhang Zhidong (Feng 2006, 160-92) and Li Hongzhang (Xie 2006, 612-21). See also Saldanha 1999.

A.H.D. Caixa 1236, copy of translated telegram from governor-general of Hubei to senior consul. 
strictest discipline and quelling the frequent civil disturbances and revolts, both Boxer and non-Boxer related. ${ }^{38}$

\section{Portuguese Defence Activities}

The main areas of the Boxer Uprising seem to have been Zhili and Shanxi, with Henan also experiencing significant disruptions. After a series of initial clashes late in 1898, notably at Sanluo Temple 三羅廟 in Shandong, resentment simmered until the murder of a British missionary in that same province at the end of 1899. Conditions were deteriorating for the international community in Beijing, and matters came to a head with the murder of a German diplomat in June 1900, coinciding with the swarming into Beijing of large numbers of Boxers. A force under Britain's Admiral Seymour was assembled at Tianjin to advance up to Beijing along the railway line in June 1900. The murder of the German diplomat, in addition to China's declaration of war against the foreign powers, signaled the start of full-fledged conflict. The Seymour expedition turned out to be a fiasco. In August a second, much larger, multinational force was assembled. It was able to lift the siege of the legations in Beijing rapidly within the month (with the victory parade being held on August 28). The subsequent Boxer Protocol was signed only a year later, after much negotiation, in September $1901 .^{39}$

While the Portuguese never went so far as to "participate in the [Allied] suppression" of the Boxer Uprising, an expeditionary force was indeed dispatched from Lisbon. ${ }^{40}$ To investigate this, it is appropriate to take a broad look at developments across Portugal's colonies in Asia. Porvir issue 123 reported that reform of the Portuguese colonial military had not been approved in parliament because there were still issues to be debated. However, it was acknowledged that military organisation in the colonies was too important to be left to those with business interests. There seemed to be a need and desire to harmonise the system so that officers and soldiers, for instance, might have better opportunities for deployment and career mobility. The irregularity in the system was causing indiscipline and gaps in the recognition of servicemen's merits, a situation that was prevalent in Africa as well as India. Also, a reorganisation

38 Xie 2006, 612-21. Beseeched by the Empress Dowager for help in the settlement talks in the later part of the crisis, Li's delaying tactic in returning to the north once again reveals his politicking instinct.

39 Foster 1913, 246-55.

40 Clarence-Smith 1985, 3 . 
might allow for better cooperation between the metropole and peripheral forces such as the company of Humbe (consisting of Portuguese and indigenous soldiers) operating in Angola. ${ }^{41}$ In the campaign in Angola, the need to call upon metropolitan troops, combined with the necessity of summoning reinforcement auxiliaries from nearby or other colonies, made the need for better organisation more urgent. Reform of the Portuguese colonial military was also needed so that Lisbon could be prepared for surprises-for instance, rebellion in India. The colonial military appeared to be unprepared for contingencies, partly due to the lack of a budget (orçamento). The Porvir article went on to point out that inefficacy in important places (some of which did not have any artillery) should not be tolerated. Until then, debate on the reform had seen the involvement of two council members (one succeeding the other), and debate had focused on the need to establish more bases. The work was so important that it could not be left entirely to senior overseas officials. In addition, a commission had been appointed under the charge of the Count of S. Januario to look into the matter. Another suggestion raised the possibility of establishing a regular nucleus of effective indigenous troops. ${ }^{42}$

In Macau, the military establishment underwent reforms over a century to present a semblance of a modernised colonial force after the inception of the first military unit there in 1784. Along the way, a section of a hospital and convent were dedicated for the recuperation of soldiers and a new hospital was built later. The engineer corps probably underwent a reorganisation after the appointment of Major António de Azevedo e Cunha, during one of the most expansive phases of the military history of Macau under Ferreira do Amaral (in office from 1846 to 1849). The military establishment at Macau went through at least two major reorganisations after 1784. Major reinforcements, albeit sporadic, came from Goa; when the situation was deemed urgent, help came from Lisbon. ${ }^{43}$

It should be noted that despite the paucity of major injections of troops and resources, communications regarding military logistical needs were fairly routine and regular. A review of communications between the governor of Macau

41 "Humbe" referred to a place and an ethnic group in the south of Angola; hence, the military company that was stationed there was named as the "company of Humbe." The Portuguese landed in West Africa in the 15th century and established the settlements of Luanda and Benguela by the 17 th century. In the second half of 19th century, intense competition for Africa by the various colonial powers led the Portuguese to step up pacification of the Bantu and non-Bantu tribes in southern Angola.

42 Porvir 133, March 1900.

43 Cação 1999, 13-29. 
(José M. de Sousa Horta e Costa) and the Secretary of State for Maritime and Overseas Affairs (Secretario de Estado dos Negocios de Marinha e Ultramar, António Teixeira de Sousa) in October 1900 reveals requests for alterations in the quantities of war materials being sent. Changes were requested to military items such as sheaths and light swords, uniforms, and cartridges of various bore sizes.

The landscape of Macau island is relatively uneven and features a number of hills. It was natural for the few elevated points on the island to be fortified and emplaced with guns. M. Teixeira gives a good overview of fortification building there. ${ }^{44} \mathrm{He}$ lists fortresses from the third quarter of the nineteenth century that were identified for repair work by the director of public works: those at Barra, Guia, Taipa, D. Maria II, Mong-ha, Bomparto, and S. Paulo do Monte (or just Monte), as well as S. João and S. Pedro. Most of them underwent a few rounds of repairs. The fortresses of Mong-ha and Monte were relatively new, while those of Guia, Taipa, and D. Maria II each went through two rounds of repairs. In the last decade of the nineteenth century the fortresses of Barra, Bomparto, and S. Francisco were recommended for demolition, although in the end only the fortress of D. Maria II was torn down. The number of guns in the various fortresses at that point was given as one hundred of "different types and calibers," including four Armstrongs (breech-loading), one Blakely (rifle), two mortars, and two howitzers. ${ }^{45}$

In defending against threats from the sea, an important focal point of attention was the Port Interior, where the naval station was based. ${ }^{46}$ It was situated west of the island of Macau, between the point at Barra and the island of Verde, and facing the island of Lapa. Despite having limited resources, Portugal was able to maintain at least a gunboat and a couple of other vessels in the naval station of Macau, a practice begun in the last quarter of the nineteenth century. ${ }^{47}$ For instance, the years 1900-1901 saw the gunboats Liberal and Zaire stationed at Macau. The Africa also served in-station during 1898 and 1901. Usually, a larger ship in the form of a cruiser was also on voyage in the area; the

\footnotetext{
44 Teixeira 1984, 71-84.

45 Cação 1999, 81-83, 126.

46 Costa 1999, 118-19. A "naval station" was "a grouping of one or more ships whose missions were coordinated by the commander of a senior ship, and they remained in an area for an extended period." See clarification in Garrett 2010.

47 Garrett 2010, 129.
} 
Adamastor served in this role during 1900-1901. ${ }^{48}$ During the militarily aggressive phase under Amaral, Macau was even touted as the "Gibraltar of China."49

The intensive phase of the Boxer Uprising occurred during an interim government of councilmen (from April 1900) and the governorship of José M. de Sousa Horta e Costa (from August 19oo, serving a second term in Macau). The council stressed the urgency of reinforcements from Portugal, and an expeditionary force did arrive under its aegis. After August 1900 the fighting in the north simmered down and negotiations began in earnest, with the Boxer Protocol being signed in September of the following year (1901). A brief reorganisation of the colonial forces occurred subsequently during the governorship of Horta e Costa. ${ }^{50}$

The arrival of a force from Lisbon led by Major António de Varnhagen Moraes Bessa in August 1900 was a conscious injection of manpower and resources in the form of an expedition. Telegraphic messages sent in June 1900 from Macau to Lisbon reveal the latter's monitoring of the situation in China and its conclusion regarding a need for more arms, as well as greater recruitment of militia. In the same month, an update from Lisbon reported that an expedition had set forth. The force that arrived in the steamship Casengo consisted of a company of three hundred gunners and a battery with six pieces of Krupp artillery and three Hotchkiss guns, as well as attached medical service and administrative personnel. It appeared that when the expedition was being conceived in March of 1900, a much larger force was planned for; the original expeditionary force had two hundred more caçadores (mounted light infantry) in the Third Company and an additional squadron of cavalry. The artillery battery was quartered at the fortresses of S. Paulo do Monte and D. Maria II de Mongha, while the company of caçadores and the service auxiliaries were put up at S. Francisco. Yet other troops were dispatched to various locations such as the palace of the governor and the hospital of S. Januario. ${ }^{51}$ The battery that was initially put up at S. Paulo do Monte was reported to have returned to Portugal in January 1902. It is unclear where the gunners were deployed after they were quartered at S. Francisco..$^{52}$ An analysis of Armando Antonio Cação's survey of troops dispatched to Macau over the period of more than four hundred years up to 1900 reveals that while it was not unusual for reinforcements and spe-

\footnotetext{
48 Cação 1999, 40-41, 44, 118.

49 Teixeira 1984, 81. The phrase was coined by Governor Ferreira do Amaral himself after an aggressive period of arming Macau and asserting its territorial rights.

50 Santos Alves 2013, 294-95.

51 A.H.M. (Lisbon) Relatorio do commandante do expediçionario a Macau em 1900.

52 Cação 1999, 102.
} 
cially designated forces to be one hundred to three hundred strong, it was not common to have expeditionary forces sent to the colony. ${ }^{53}$ The sending of an artillery force can be readily understood as a defensive measure in anticipation of any incursion that might take place against the colonial settlement. The emphasis on defense may be seen also in the upgrading of guns (breech-loading and quick-firing) — with well over a thousand rounds of shells—as well as the efforts to upgrade the forts and their guns over the course of the nineteenth century. ${ }^{54}$ The forces were on the whole well supplied, and the commander in his report commented on the soldiers' clothing for the various seasons. The report by the medical officer showed that the numbers of soldiers reporting sick did not increase during the period of their stay. ${ }^{55}$ The expenses associated with

53 Cação 1999, 13-23. At times, these large reinforcements were designated as "expeditions." It was also not uncommon for transitory figures (replenishment and those departing for other colonies or the metropole) following the incoming and outgoing monsoon voyages to fluctuate in tens in a garrison that numbered between 250 and 400.

54 Garrett 2010 is unclear as to whether the breech-loading and quick-firing guns were available in 1900. A list of guns in Macau given in the appendices of the book is dated in September 1899 certainly does not clarify the matter either. This is perhaps not surprising in a book covering defence and military developments at Macau over an extended period of 450 years. The analysis of many of the events and milestones is necessarily limited given the wide coverage. The other drawbacks of the book are its very brief citations (which do not appear to include any Portuguese sources) and its failure to provide a separate treatment on the defence situation during the Boxer Uprising (highlighting humbly and hopefully the need for the current essay). These limitations notwithstanding, Garrett's work is comprehensively written, being organised along chronological and thematic lines; the latter with particular attention to weapons (artillery, small arms, etc.). The navy is separately treated in a chapter. A strong feature of the book is that Garrett, being an antique firearms collector as well as a member of the Arms and Armour Society, is keenly attuned to the extant collections of military relics in Macau's museums. The details presented of the arms and pieces will certainly attract military historians and enthusiasts. Garrett is also well traveled in the ex-colony of Portugal and is aware of the surviving structures that are associated with military and defence uses there. These are amply illustrated in photographs and, where the structures no longer exist, Garrett is able to draw and reproduce these from photographs and pictures from the museums and archives of Macau. Overall, Garrett's work is a worthy contribution to the field of the military defence of Macau.

55 A.H.M. (Lisbon) Relatorio do commandante do expedição a Macau em 1900; relatorio pelo tenente-medico sobre expedição a Macau. The numbers were elevated for the period they were on their way to Macau, with more soldiers being reported as anemic and asthmatic. 
the military expedition from Portugal to Macau amounted to 89,584 xerafins and 23 tangas. 56

More than just tending to its own defense, Macau also acted as a coordinating point for the consulates set up in China. According to documents of the General Directorate (Overseas) pertaining to the province of Macau during the second half of 1900, there appears to have been a serious attempt to raise a volunteer mercenary force in Macau. There was also an attempt to raise a force of volunteer riflemen from the Portuguese community in Shanghai to be led by the Portuguese consul there. The Shanghai consulate would also send a military instructor to Macau to assist with the defence of the settlement. ${ }^{57}$ A document illustrates the discussion involved in the procurement of arms from Shanghai for Macau:

the Japanese infantry ... possess a new rifle that is being distributed from the army that brings together all the conditions of good modern arms. [A decision is to be made via the middleman whether] the Japanese [arms] or the Lee-Metford adopted by the English volunteers, subordinate to other considerations, [is to be bought] in Hong Kong. 58

Whenever an uprising occurred across the border in Guangdong, with associated tensions in the surrounding areas, it became difficult to obtain or ship military hardware to Macau. Telegraphic exchanges between the metropole and Macau affirmed the call for intercession not only by the colonial authorities but also by the foreign affairs ministry-but matters in this regard were not always resolved. Although the Portuguese did not raise a volunteer military force in Shanghai, tensions from the general upheaval were acutely felt in that

$5^{6}$ One xerifim was equivalent to 2 rupia or Indian rupees or 32 tangas. In terms of the general military expenditure (land force), Macau's percentage (about 25 per cent) compared well with that of India and was higher than that of Mozambique (the pride of the empire), although the absolute figure for the latter was greater. With regard to the navy, Macau's proportion was higher than that of India ( 0.05 per cent as against 0.01 per cent) but lower than Mozambique's (в.о. No 43).

57 Shanghai was in as precarious a state as Macau during the Boxer Uprising. During the Taiping Uprising, Shanghai was threatened and the defence put up by combined British and French forces managed to repel the enemy. One should not forget the contribution (if limited) of the military forces trained along Western lines and led by F. T. Ward and C. G. Gordon.

$5^{8}$ A.H.M. (Macau) SSC Repartição Militar, SR 004 1900-1902; $4^{\mathrm{a}}$ Repartição, $1^{\mathrm{a}}$ Secção / Processo No 18 / 1900 / Part 4 / 5. The subordinate considerations included whether munitions could be procured promptly. 
city. The volunteer force raised by the other imperialist powers in Shanghai contributed to the Allied expedition to Beijing in August. ${ }^{59}$ It should also be borne in mind that part of the plotting and organisation of the revolution of August 9, 1900, by the compatriots of Tan Sitong was made in Shanghai. ${ }^{60}$ Nearer to Macau, there was a similar attempt to raise an armed body of Portuguese at Canton. In Hong Kong, the strength and equipment of the colony's volunteer force was improved in response to the heightened tension there, although the mobilisation of this volunteer military force did not involve the Portuguese authorities in any way. ${ }^{61}$

Other than the internal strife that could potentially threaten Macau, there was a possible threat from the Qing military across the border. The Chinese military was usually viewed with amusement by Western observers (due to the country's repeated humiliation in the nineteenth century), though on occasion a telegram update (such as that of July 190o) conveyed "excitement" (that is, concern) about Qing military maneuvers occurring across the border. On the whole, although the defence of Macau hoped to rely on a reliable arrangement of replenishment and a judicious deployment of its miniscule forces, debates were sometimes invoked among the Macanese officials whether the settlement should expand its boundaries as a strategy of defence. This was especially true when the move was supported by the maneuverings of the major imperialist powers. ${ }^{62}$

\section{A Word on the Aftermath}

Although the Boxer upheaval appeared to end in 1900, its reverberations continued beyond that year. Regarding larger concerns about the colonial military, one can see that there was already an interest in improving the state of affairs, which culminated in the commission of S. Januario in the 189os. Important reforms in overseas defence, passed in a decree, were implemented at about

59 Although frequent mentions were made of Shanghai in the documents collected in the Macau Archive, there was no requirement that correspondence between Shanghai and Lisbon be routed through Macau. Documents pertaining to communication between the consul at Shanghai and the metropole are likely to be stored at the Ministry of Foreign Affairs Archive.

6o Wu 1991, 23. Remnants of the surviving revolutionaries of the 9 August 1900 uprising fled to Shanghai after the failure of the attempt.

61 Harfield 1990, 356. The Portuguese maintained a community of some size in Hong Kong.

62 A.H.M. (Macau) ssc: Repartição Militar, SR 004 1900-1902. 
the same time that the Boxer Protocol was signed in 1901. Implementation of the reforms took several years-right up to the eve of the change of regime in Portugal — and featured changes in several areas. The Macau military units were reorganised into a company of European infantry and artillery, a company of reformados, ${ }^{63}$ a body of police consisting of two companies of infantry, and a platoon of cavalry. The main military units were to be supported by auxiliary units such as a quartermaster service with a depot for materials of war, a medical company, and an indigenous military musical band. The military fortress of S. Paulo do Monte (or Monte), which was relatively new, would house the most modern guns arriving with the expedition and would be designated as an important site in the defense of Macau.

Part of the expeditionary force that was brought over from Portugal to Macau in August 1900 became part of the long-term garrison when the decree on the reform of the Portuguese colonial military was executed in January 1902, and continued to serve in this role until 1918. This indicates the continuity between the 1900 expedition and the restructuring. With regard to the fortress of Monte, this was the first time that troops garrisoning the fortress were grouped into military units. ${ }^{64}$ Armed with state-of-the-art artillery pieces, the fortress was recognised as an "overseas praça (fortress) of war" in the revived network of bases. The European infantry unit, which seemed to be unrelated to the expeditionary force and drawn partly from previous garrisons, was stationed at the Porta do Cerco and the barracks of Flora in $1902 .{ }^{65}$ This was supposedly to "allow rotation and career advancement" as well as "beef up indigenous forces," both of which agendas were raised in the discussion on Portuguese colonial military reform. At the same time, the regular nucleus of more effective local troops was to be raised through the formation of a police force-consisting, again, of a company-size unit of Europeans and another of indigenous people (made up of natives of India and Macau), as well as a cavalry platoon. Despite an earlier newspaper report of an over-militarised police force, ${ }^{66}$ the police force-complete with an indigenous military band — seemed to be more militarised than before. It was quartered at S. Francisco and several other places from the old port on the mainland to Coloane and Taipa. Apparently, there was also a reorganised company of men and a body of volunteers being formed at

63 Reformed men, referring to ex-convicts who received some form of corrective program and training.

64 Cação 1999, 74.

65 Cação 1999, 128-29, 132.

66 A.H.M. (Macau) SSC: Repartição Militar, SR 004 1900-1902; $4^{\text {a }}$ Repartição, $1^{\text {a }}$ Secção / Processo No 18 / 1900. 
the same time-though it was not clear how these were linked to the police force, or whether they were related to each other. At the top of the hierarchy, the portfolio and powers of the Secretary of the Military of the Province of Macau and Timor, created as early as 1875 , were activated only belatedly by the decree on reform in November 1901, more than twenty-five years later. ${ }^{67}$

Telegrams between Lisbon and Macau were, not surprisingly, preoccupied with defence and associated matters of finance. Whether surveying materials from 1900 or from 1901, we find entries on monetary matters. Telegraphic exchanges reveal numerous requests for monetary assistance from the metropole. This is surprising, because the metropole had become mired in foreign debt in the 1890s. Other entries deal with allocations for garrisons, on top of remittances (for example, to Timor), bank transfers (for example, to the Hong Kong and Shanghai Bank Corporation), and requests for updates to financial statements pertaining to fortresses so that projections could be made of future budgets (orçamento). ${ }^{68}$ While the establishment of a branch of the National Overseas Bank in Macau in 1902 in the aftermath of the Boxer upheaval might have been coincidentally timed, the crisis did expose the excessive reliance of the colony on foreign banking institutions for its overseas operations, especially the transfer of funds.

Wu Zhiliang has introduced a chronological model for viewing the negotiating prowess of the Qing and Portuguese governments in relation to the jurisdictional authority that each side had over Macau. ${ }^{69}$ Although neither the Ming Chinese nor the Manchus initiated a hostile takeover, their hold on Macau had been firm until the beginning of the nineteenth century. This negotiating prowess began to shift in favor of the Portuguese as the major imperialist powers began to assert themselves across the globe. Internally, this also coincided with the metropole's attempt-in conjunction with its modernising and centralising tendencies-to impose itself on its overseas colonies. In the aftermath of the Boxer Uprising, the Qing government was subjected to a series of clauses that they accepted in the protocol of September $1901 .^{70}$ It appears that the Portuguese attempted to profit from the post-Boxer situation as they had done in the aftermath of the Opium War-the Collected Records of the Qing Foreign Affairs Office (on Sino-Portuguese relations) reveal occasional entries on particular clauses asserting Portuguese interests. ${ }^{71}$ More important,

67 Cação 1999, 158.

68 A.H.M. (Macau) SSC 1 ${ }^{a}$ Repartição, SR 001, 1900.

69 Wu 2010, 80-149.

70 The Qing court acceded to the demands in January 1901.

71 First Historical Archives 2004, 1-20. 
Sino-Portuguese exchanges leading up to 1902 urged a review of the 1887 treaty. Of crucial importance was Macau's right to occupy nearby islands and territories in the neutral or buffer zones as well as have full jurisdiction over the territories already under its control (implying that Mandarin officials, for instance in Xiangshan 香山, should not be interfering in Macau's affairs). It should be noted that those on the Portuguese side did not always see eye to eye with one another regarding the negotiations; the editor of Ta-Ssi-Yang-Kuo, for instance, was especially critical of the negotiations begun and led by José de A. Castelo Branco, appointed in 1903 as the first plenipotentiary ambassador of Portugal in China.

On the ground, diplomatic developments were taking place more slowly and less concretely. The Boxer Uprising led to developments that complicated Portugal's attempt to secure favourable pledges from China in relation to jurisdiction over the areas and waters surrounding Macau. A look at documents from 1900, 1902, and 1909 reveals the persistent issues plaguing the negotiations and the revision of the 1887 Peking treaty in the immediate aftermath of the uprising, as well as the impasse faced by Portugal's commission of 1909-a group led by general diplomat Joaquim José Machado to look into the treaty. Three important issues highlighted in the documents were as follows: the question of territory and jurisdiction around Macau, which hinged to some extent on the willingness of the Qing authorities to recognise and resolve the issue; commerce or fishing undertaken in the disputed areas or involving disputed commodities; and members of the Boxers, secret societies, and revolutionary societies who were of concern to either side. Territoriality had, in connection with the issue of commerce and tariff collection, evolved over time to include an array of disputes. In the attachment to Horta e Costa's report, the peninsula of Macau, the island of Ma-lan-chau, and the island of Coloane were claimed within the "blue line indicated in the [document]." Macau considered the islands outside the settlement to be "strategic points in order for it to pursue its defence." 72

From an economic perspective, Macau's close links with its surrounding areas also had the potential to create a growth area sustained by resources, production, and markets. In order to continue its trade and livelihood, Macau depended on the autonomy of the islands of D. João, Lapa, and Vong-cam as well as the waters surrounding them. The "island" of Hung-shan (Heung-shan or Xiangshan) was endowed with "factories and centers of productions" whose

72 A.H.D. (Lisbon) Caixa 1236, Relatorio do conselheiro Horta e Costa, 24 September 1900. 
products were transported for the ports. ${ }^{73}$ China's inability to patrol the coastal seas and islands in disputed areas was beneficial to Portuguese economic activities and commerce. The inhabitants of Taipa island had been requesting the Portuguese authorities to protect them against local criminals, and the Portuguese deployed a naval and garrison presence there from the 185os; the inhabitants of D. João also asked for help against pirates who had attacked the island in the 188 os. According to Joaquim José Machado's report, the Qing authorities had either tried to return to Lapa, D. João, and Vong-cam in the 1890 s or challenged the Portuguese presence there. The report highlighted the issue of whether fishing junks from certain islands such as Lapa could operate in the neighboring seas, which had implications for the debated jurisdictional sphere of control of the Portuguese in Macau. ${ }^{74}$

The Boxer Uprising raised awareness of the potentially disruptive activities of secret societies and the unsavoury characteristics of their participants that could threaten Western settlements and communities in China. The Chi Chi Ui (Zizhi Hui 自治會) was one secret society mentioned in the document on a few occasions. From the perspective of the Qing government, the repatriation of revolutionary party or secret society members hiding in Macau was a matter of persistent concern. Other than issues of territoriality, tariffs and payments, and revolutionaries and secret society members, there was the more immediate question of compensation for Portuguese properties that had been damaged in north China during the uprising, such as the library of the consulate in Tianjin. This issue was raised in the Boxer Protocol negotiations, although it was eventually left out of the final treaty. Machado's final assessment was that Macau's military force need not be greatly augmented as the problem of Macau would crop up time and again whenever there was a crisis. ${ }^{75}$ The entries in the Collected Records of the Qing Foreign Affairs Office dealt with a variety of matters, not all confrontational. Discussions on potential cooperative

73 Caixa 1234, Relatorio pelo Alto Comissário Gerneral Joaquim José Machado, 27 November 1909, $7-8$.

74 A.H.D. (Lisbon) Caixa 1236, Relatorio do conselheiro Horta e Costa, 24 September 1900.

75 A.H.D. (Lisbon) Caixa 1234, Copia do documento de Legação de Portugal na China, Japão e Siam, 4 May 1901; Caixa 1234, Relatorio pelo Alto Comissário General Joaquim José Machado, 27 November 1909, 55-58. The British represented the Portuguese claims in the Boxer Protocol negotiations, and Spain also spoke on behalf of Portugal. It appeared that the Tianjin claim was omitted in the end, although Portuguese interests were considered along with the benefits negotiated by the major powers. 
ventures, for instance in mining and railroads (specifically the Macau-Canton railway), were held between officials and investors from both sides. ${ }^{76}$

\section{Conclusion}

Whether viewing the Boxer Uprising as an event or an experience, to use Cohen's terms, it has developed enormously as a field of study. Even if one is just analysing events, the field is far from being saturated. This essay has explored the military activities centered on Macau during the Boxer Uprising crisis. While Macau was not subjected to outright incursions by China or the other imperialist powers, major upheavals in China produced their share of jittery reactions in Macau, as had been the case during the Taiping Uprising. The unwillingness of Qing officials in the south to declare war on the imperialist powers should have meant there would be little upheaval there. However, this turned out not to be the case, as groups sympathetic to the uprising in the north —or taking advantage of it - used the opportunity to rise against the authorities. Troublemakers related or unrelated to the Boxers, as well as the revolutionaries in south China, may not have fitted the full description of Boxers-who were anti-Western, practiced martial arts, and engaged in spiritpossession rituals. They nevertheless posed a threat to Macau, perceived or real, which required a stepping up of the city's defence and security.

Macau's response to the threat took several forms. Its telegraphic exchanges with Lisbon provided updates on the crisis up north as well as trouble brewing in its own vicinity. Meanwhile, its requests for personnel, and even monetary transfers, never ceased. Coherent and revised plans were put in place for the deployment of forces in the settlement. Beyond the confines of the settlement, Macau acted as an important coordinating point for the Portuguese consular stations in China. Macau officials helped in the recruitment of volunteer and specialist personnel. The governors of Macau as well as specially appointed diplomats-in consultation with their counterparts from other imperialist powers, especially Britain - contemplated moves for the expansion of territory to improve the defence situation. Eventually an expeditionary force did arrive from the metropole. Although the force was not involved in any major action, its arrival demonstrated the urgency of the situation in south China and also Lisbon's larger plan for renewal and upgrading of the military in its

76 First Historical Archives 2004, 1-20; A.H.D. (Lisbon) Caixa 1236, Relatorio do conselheiro Horta e Costa, 24 September 1900. 
far-flung colonies. In terms of finances, Macau was not only able to sustain itself but also aided other, less profitable colonies. Its expenditures on the military as well as the navy compared favourably with those of other important colonies in the empire, such as Mozambique.

Portugal was able to press China for a reconsideration of the 1887 treaty, although no major breakthrough was made in the aftermath of the uprising or even until the 1909 mission of Joaquim José Machado. The expeditionary force sent from Portugal was dispersed into various fortresses and units in Macau. For China, the signing of the Boxer Protocol increased the dissent and revolts that had first been triggered after the Sino-Japanese War of 1894-95. Even if the Qing court had acceded to more profound reforms after 1900, its decline appeared too far gone to reverse. On the other side of the world, a monarchy's unwillingness to devolve power led also to the overthrow of Portugal's constitutional monarchy in 1910. The deep fiscal debts of the preceding decade, aggravated by colonial deficits, played a part in the toppling of the monarchy, although Macau itself appears to have contributed positively to the empire. On a worldwide scale, the reaction to Russian overtures in the Far East was the Anglo-Japanese Alliance of 1902. The precarious second Open Door Policy (before the Boxer Protocol) and the Russian occupation of Manchuria set off a sequence of alliance forming, aggravated by colonial competition, that led to the First World War-a war in which both China and Portugal participated on the side of the Entente Powers.

\section{Bibliography}

\section{Manuscript Sources}

\section{A.H.M. Arquivo Histórico Macau (Macau)}

Fundo Secretaria de Estado da Marinha e Ultramar, SSC: 1a Repartição, SR oo1: Saida de Correspondência para Macau e Timor, 1897-1901 (CO721).

Fundo Secretaria de Estado da Marinha e Ultramar, Direcção-Geral do Ultramar, SSC: Repartição Militar, SR 004: Gerais de Macau, 1900-1902 (CO840).

Boletim Official (в.о.), 1900-1901.

\section{A.H.M. Arquivo Histórico Militar (Lisbon)}

Relatorio do commandante do expediçionario a Macau em 1900.

I.A.C.M. Biblioteca do Edificio do Instituto para os Assuntos Cívicos e Municipais (Macau) Porvir

A.H.D. (M.N.E.). Arquivo Histórico Diplomático (Ministério dos Negócios Estrangeiros) (Lisbon) Caixa 1234, Caixa 1236. 


\section{Printed Primary Sources}

TSYK Pereira, João F., ed. Ta-Ssi-Yang-Kuo 大西洋国 [The Great Eastern Country], vol. II. Macau: Fundação Oriente, 1995.

First Historical Archives of China and Macau Technical College (Beijing University), eds. 2004. Qing dai wai wu bu zhong wai guanxi dang'an shiliao congbian [The Collected Records of the Qing Foreign Affairs Office: Sino-Portuguese Relations Roll], vol. 1. Beijing: Zhonghua shuju.

First Historical Archives of China. 1995. Aomen zhuandang [Collected Records on Macau]. Taipei: Academia Sinica.

Foster, John. 1913. Memoirs of the Viceroy Li Hung Chang. London: Constable and Co.

$\mathrm{Wu}$ Ruguan, ed. 1997. Li Hongzhang quan ji [Complete Collected Writings of Li Hongzhang]. Haikou: Hainan Press.

Zhi Xin Bao 知新报 [Newspaper for Acquainting with New Knowledge], 2 vols. Macau: Aomen jijinhui, 1999.

\section{Monographs and Articles}

Abrantes, M. 1999. Macau e o Oriente. Macau: I.C.M.

Bing Sang. 2004. Gengzi qin wang yu wan Qing zhengju [The "Gengzi qin wang" Movement and the Political Situation of the Late Qing Dynasty]. Beijing: Beijing University Press.

Cação, A. A. 1999. Unidades militares de Macau. Macau: Gabinete da Força de Segurança de Macau.

Chang, Hao. 1980. "Intellectual Change and the Reform Movement, 1890-8." In John K. Fairbank and Kwang-ching Liu, eds. Cambridge History of China, vol. 11, pt. 2. Cambridge: Cambridge University Press, 274-338.

Clarence-Smith, W. G. 1985. The Third Portuguese Empire, 1825-1975: A Study in Economic Imperialism. Manchester: Manchester University Press.

Cohen, Paul A. 1997. History in Three Keys: Boxers as Event, Experience, and Myth. New York: Columbia University Press.

Costa, R. da. 1999. A marinha Portuguesa em Macau. Macau: Capitania de Portos de Macau.

Esherick, Joseph. 1987. The Origins of the Boxer Uprising. Berkeley: University of California Press.

Feng Tianyu. 2006. Zhang Zhidong ping zhuan [A Critical Biography of Zhang Zhidong]. Nanjing: Nanjing daxue chubanshe.

Feuerwerker, Albert. 1984. "Economic Trends in the Late Ch'ing Empire, 1870-1911." In John K. Fairbank and Kwang-ching Liu, eds. Cambridge History of China, vol. 11, pt. 2. Cambridge: Cambridge University Press, 1-69. 
Harfield, Alan. 1990. British and Indian Armies on the China Coast. Farnham, UK: A\&J Partnership.

Hsu, Immanuel C.Y. 1980. "Late Ch'ing Foreign Relations, 1866-1905." In John K. Fairbank and Kwang-ching Liu, eds. Cambridge History of China, vol. 11, pt. 2. Cambridge: Cambridge University Press, 70-141.

Garrett, Richard. 2010. The Defences of Macau. Hong Kong: Hong Kong University Press.

Graça, Jorge. 1984. The Fortifications of Macau. Macau: Imprensa Nacional Macau.

Jansen, Marius B. 1954. The Japanese and Sun Yatsen. Cambridge, MA: Harvard University Press.

Kennedy, Paul M. 1989. The Rise and Fall of the Great Powers: Economic Change and Military Conflict from 1500 to 2000. London: Fontana.

Liang Qichao. 1998. Li Hongzhang zhuan [Biography of Li Hongzhang]. Chongqing: Chongqing chubanshe.

Ljungstedt, Andrew. 1836. An Historical Sketch of the Portuguese Settlements in China. Boston: James Munroe \& Co.

Purcell, Victor. 1963. The Boxer Uprising: A Background Study. Cambridge: Cambridge University Press.

Saldanha, A.V. de. 1996. "As conferências inter-governamentais de 1909 para a delimitação de Macau e o seu significado nas relaçðes Luso-Chinesas." In A. V. de Saldanha, ed. Estudos sobre as relações Luso-Chinesas. Lisbon: I.s.C.s.P., 589-612.

Saldanha, A. V. de. 1999. "Reformismo e conservadorismo: O Vice-Rei Zhang Zhidong e a questão de Macau." In Jorge M. dos Santos Alves, coord. Portugal e a China: Curso livre de história das relações entre Portugal e a China. Lisbon: Fundação Oriente, 125-38.

Santos Alves, Jorge M. dos, coord. 1999. Portugal e a China: Curso livre de história das relações entre Portugal e a China. Lisbon: Fundação Oriente.

Serrão, Joaquim V. 1977-2010. História de Portugal. 18 vols. Lisbon: Editorial Verbo.

Shipp, Steve. 1997. Macau, China: A Political History of the Portuguese Colony's Transition to Chinese Rule. Jefferson, NC: McFarland \& Co.

Silbey, David. 2013. The Boxer Rebellion and the Great Game in China. New York: Hill and Wang.

Sim, Teddy. 2007. "A Probe into Macau's Political Economy and Trade Relations during the Mid-Qianlong / Pombaline Period." Revista de Cultura 24 (2007), 106-20.

Tan, Chester. 1967. The Boxer Catastrophe. New York: Octagon Books.

Teixeira, Manuel. 1984. "Macau e os Piratas." In M. Teixeira, ed. Os militares em Macau. 2nd edition. Macau: Imprensa Nacional, 340-41.

Wang Yutang. 1990. Liu Kunyi ping zhuan [A Critical Biography of Liu Kunyi]. Guangzhou: Jinan daxue chubanshe. 
Wu Qu. 1991. Xinhai geming shi ditu ji [History of Xinhai Revolution Map Collection]. Beijing: Zhongguo ditu chubanshe.

Wu Zhiliang. 2010. Aomen zhengzhi zhidu shi [History of Macau's Political System]. Guangzhou: Guangdong renmin chubanshe.

Xiang, Lanxin. 2003. The Origins of the Boxer War: A Multinational Study. London: Routledge.

Xie Shicheng. 2006. Li Hongzhang ping zhuan [A Critical Biography of Li Hongzhang]. Nanjing: Nanjing daxue chubanshe.

Yu Shenwu. 1994. Shijiu shiji de Xianggang [Hong Kong of the Nineteenth Century]. Hong Kong: Qilin. 